\title{
Possibilities of the Use of Fast Scan Voltammetry in Simultaneous Determination of Purines at Carbon Fiber Ultramicroelectrodes
}

\author{
Éder T. G. Cavalheiro ${ }^{a, b^{*}}$, Kholoud A. El-Nour ${ }^{a, c}$ and Anna Brajter-Toth ${ }^{a}$ \\ ${ }^{\mathrm{a}}$ Department of Chemistry, University of Florida, Gainesville-FL, USA \\ ${ }^{\mathrm{b}}$ Departamento de Química, Universidade Federal de São Carlos, \\ Via Washington Luís, Km 235, 13565-905, São Carlos - SP, Brazil \\ ${ }^{\mathrm{c}}$ Department of Chemistry, University of Suez-Canal, Ismailia, Egypt
}

\begin{abstract}
Hipoxantina, xantina e ácido úrico são purinas encontradas em fluídos extracelulares, que podem ser utilizados como marcadores metabólicos, indicadores da idade de carnes e outras aplicações. Estudos voltamétricos foram desenvolvidos para investigar a possibilidade da determinação simultânea destes analitos em ultramicroeletrodos de fibra de carbono (diâmetro de $7 \mu \mathrm{m}$ ). Os estudos efetuados mostraram a possibilidade destas determinações com coeficientes médios de recuperação da ordem de $97,6 \%$, ao nível de $\mu \mathrm{mol} \mathrm{L}-1$.
\end{abstract}

Hypoxanthine, xanthine and uric acid are purines present in extracellular fluids that can be used as metabolic markers, in evaluation of meat conservation and other applications. Voltammetric studies were performed in order to investigate the possibility of simultaneous determination of these compounds using carbon fiber ultramicroelectrodes ( $7 \mu \mathrm{m}$ diameter). The studies revealed the possibility for performing such determinations with mean recoveries of $97.6 \%$ in mixtures of the three compounds at $\mu \mathrm{mol} \mathrm{L}{ }^{-1}$ level.

Keywords: xanthine, hypoxanthine, uric acid, carbon electrodes, fast scan voltammetry

\section{Introduction}

Oxypurines xanthine (XA), hypoxanthine (HX) and uric acid (UA) are products of metabolism of nucleotides ${ }^{1}$ and can be found in extracellular fluids. Their determination is important since they can be related with the depletion of adenosine triphosphate (ATP) in tissues ${ }^{2}$ and are the final products of purine metabolism in humans. Overproduction of UA can cause gout ${ }^{3,4}$.

Chromatographic methods for purine determination are summarized in reviews ${ }^{5}$. Electrochemical methods include stripping of $\mathrm{Cu}$ (II) complexes $^{6-10}$, adsorptive stripping of purines from $\mathrm{Hg}^{11}$. Immobilization of the enzyme xanthine oxidase to electrodes has also been used $^{12-15}$, as it catalyses the conversion of XA and HX to UA. Recently we evaluated the performance of carbon electrodes and carbon fiber ultramicroelectrodes in

*e-mail: cavalheiro@dq.ufscar.br

Presented at the XI Simpósio Brasileiro de Eletroquímica e Eletroanalítica, Maragogi - AL, Brazil, April 5-9, 1999. Guest editor: Luis Alberto Avaca. amperometric determination of $\mathrm{XA}$ and $\mathrm{HX}$, in relation to the surface activation in different techniques ${ }^{16}$.

In the present study the possibilities of simultaneous determination of XA, HX and UA are investigated at carbon fiber ultramicroelectrodes. The interference of uric acid generated in xanthine oxidation is evaluated using fast scan voltammetry in phosphate buffer at physiological $\mathrm{pH}$, with the advantages of a miniaturized system.

\section{Experimental}

All the chemicals were of analytical grade and used without further purification. The experiments were performed in $70 \mathrm{mmol} \mathrm{L}^{-1}$ phosphate buffer at $\mathrm{pH}$ 7.4.

The instrumental setup as well as the carbon fiber ultramicroelectrode (CF-UME) preparation have been described earlier ${ }^{17}$. Briefly, a triangular waveform from a function generator (Universal Programmer PAR-175 EG\&G) was applied to a two electrode cell ( $80 \mu \mathrm{L}$ internal volume). The current at the CF-UME was monitored using an oscilloscope (Le Croy - 9310) coupled to a home made pre-amplifier ${ }^{18}$. A microcomputer was employed for data 
acquisition. The reference in all measurements was a saturated calomel electrode (SCE).

The CF-UME was electrochemically pretreated by successively cycling the electrode in $70 \mathrm{mmol} \mathrm{L}^{-1}$ phosphate buffer $\mathrm{pH} 7.4$ between +1.5 and $-1.0 \mathrm{~V}$, for 30 minutes at $10 \mathrm{~V} \mathrm{~s}^{-1} 17$.

The voltammograms were measured between +1.5 and $-1.0 \mathrm{~V}$, at $10 \mathrm{~V} \mathrm{~s}^{-1}$. Initially the mean of a fixed number of background scans was recorded in one channel of the oscilloscope. The same number of scans was taken for the sample and the mean stored in a second channel of the oscilloscope, then subtracted from the previously stored mean background signal. The currents were measured at the potential of maximum signal around $+1.2(\mathrm{HX}),+0.8$ (XA), and $+0,5 \mathrm{~V}(\mathrm{UA})$ relative to the $\mathrm{SCE}$.

\section{Results and Discussion}

\section{Simultaneous determination of $X A$ e $H X$}

Background subtracted voltammograms of $100 \mathrm{mmol} \mathrm{L}^{-1}$ of XA and HX in $70 \mathrm{mmol} \mathrm{L}^{-1}$ phosphate buffer, $\mathrm{pH} 7.4$, after 100 cycles $\left(10 \mathrm{~V} \mathrm{~s}^{-1}\right)$ at electrochemically pretreated CF-UME are presented in Figure 1.

Attribution of the peaks was discussed by Hansen and Dryhurst (XA) ${ }^{19}$ and by Conway and coworKers $(\mathrm{HX})^{20}$.

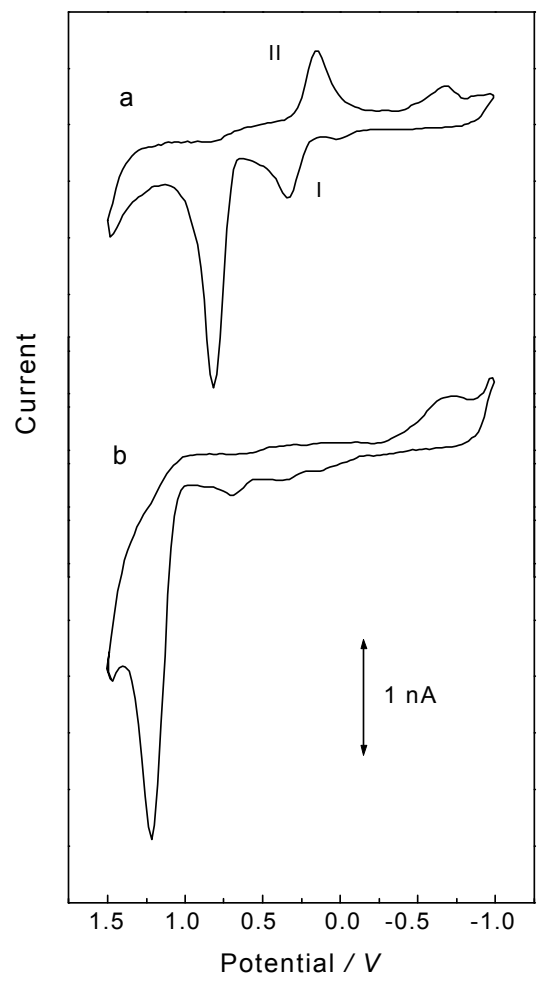

Figure 1. $100 \mu \mathrm{mol} \mathrm{L}^{-1} \mathrm{XA}$ (a) and $\mathrm{HX}$ (b) voltammograms at

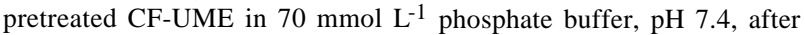
100 cycles at $10 \mathrm{~V} \mathrm{~s}^{-1}$.
Peaks I and II in the XA voltammogram were related to the UA (generated in the XA oxidation) reversible redox process, and presented no influence in the XA determination. At lower scan rates $\left(<500 \mathrm{mV} \mathrm{s}^{-1}\right)$ these peaks were not observed $^{21}$ and should not interfere in the UA current.

Typical results for simultaneous determination of XA and HX are shown in Figure 2, at pretreated CF-UME, after 100 cycles at $10 \mathrm{~V} \mathrm{~s}^{-1}$, under conditions that have been established earlier ${ }^{22}$. The currents were measured at the potential of maximum signal and the results presented in Table 1. From the data it is possible to conclude that XA and HX can be determined simultaneously. Data for individual XA and HX are also shown in Table 1.

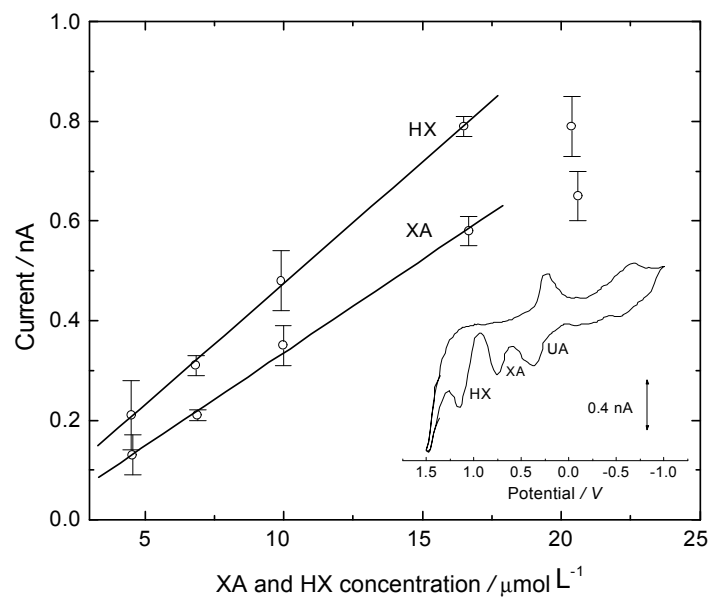

Figure 2. Analytical curves for simultaneous determination of $X A$ and HX, under the conditions described in Table 2. In the detail a voltammogram of a mixture of XA and HX both $17 \mu \mathrm{mol} \mathrm{L}^{-1}$.

Table 1. Analytical results for individual purines and mixtures of $\mathrm{XA} / \mathrm{HX}$ and $\mathrm{XA} / \mathrm{UA}^{\mathrm{a}}$.

\begin{tabular}{cccc}
\hline Analyte & $\begin{array}{c}\mathrm{LOD}^{\mathrm{b}} \\
\mu \mathrm{mol} \mathrm{L}\end{array}$ & $\begin{array}{c}\mathrm{LDR} \\
\mu \mathrm{mol} \mathrm{L}\end{array}$ & $\begin{array}{c}\text { Sensitivity } \\
\mathrm{A} \mathrm{L} \mathrm{mol}^{-1} \mathrm{~cm}^{-2}\end{array}$ \\
\hline XA & 6 & $6-30$ & 101 \\
HX & 2 & $2-30$ & 79.8 \\
UA & 1 & $2-20$ & 112 \\
Mixtures (1:1 / mol L-1) & & & \\
XA & $4^{\mathrm{c}}$ & $4-17$ & 95.7 \\
HX & $4^{\mathrm{c}}$ & $4-17$ & 124 \\
$\mathrm{UA}^{\mathrm{d}}$ & - & $4-20$ & 42.2 \\
UA in presence of XA & & & \\
XA 5 $\mu \mathrm{mol} \mathrm{L}^{-1}-10 \mathrm{~V} \mathrm{~s}^{-1}$ & 2 & $4-15$ & 109 \\
- 500 V s & 2 & $2-20$ & 468 \\
XA 15 $\mu \mathrm{mol} \mathrm{L}^{-1}-10 \mathrm{~V} \mathrm{~s}^{-1}$ & 2 & $4-8$ & 15.6 \\
$-500 \mathrm{~V} \mathrm{~s}^{-1}$ & 2 & - & 286
\end{tabular}

a. $70 \mathrm{mmol} \mathrm{L}^{-1}$ phosphate buffer, $\mathrm{pH} 7.4$, UME radius $3.5 \times 10^{-4} \mathrm{~cm}$, scan rate $10 \mathrm{~V} \mathrm{~s}^{-1}, 100$ cycles; b. Limit of Detection $=3 \times$ peak-topeak noise; c. estimated from $3 \mathrm{x}$ the peak-to-peak noise; d. generated in xanthine oxidation; e. supposing $100 \%$ XA converted to UA.

\section{Interference of XA on the UA signal}

Since the UA generated by XA oxidation shows a significant signal under the scan rates used in the present 
work, it could interfere in the UA determination when both $\mathrm{XA}$ and UA are present in the same solution.

In order of evaluate the influence of the UA generated in XA oxidation on the signal of the UA present in the same sample and the possibility of reducing the interference by increasing the scan rate, mixtures of UA in different concentrations and fixed XA were prepared and their cyclic voltammograms were recorded at 10 and 500 $\mathrm{V} \mathrm{s}^{-1}$. The results are shown in Figure 3.

At $10 \mathrm{~V} \mathrm{~s}^{-1}$ in the presence of $5 \mu \mathrm{mol} \mathrm{L}-1$ XA, the UA presented the same sensitivity as in the absence of XA, suggesting that under such conditions there is no influence from XA in UA determination. When XA was fixed at $15 \mu \mathrm{mol}$ $\mathrm{L}^{-1}$, the LDR (linear dynamic range) for UA is shorter and the sensitivity decreased significantly. The UA current increased exponentially over $8 \mu \mathrm{mol} \mathrm{L}{ }^{-1} \mathrm{UA}$, showing a significant influence of XA on UA determination at this concentration level. It is interesting to note that the current measured for UA generated in XA oxidation is higher than the XA current in this case. The decrease of UA sensitivity may be caused by the adsorption of XA (or its oxidation products) on the electrode surface. When the determination is performed at $500 \mathrm{~V} \mathrm{~s}^{-1}$, the inter-ference of $5 \mu \mathrm{mol} \mathrm{L}-1$ XA in UA current is lower, as the XA signal is significantly reduced at such scan rate ${ }^{18}$. When $15 \mu \mathrm{mol} \mathrm{L}{ }^{-1} \mathrm{XA}$ is present the LDR for UA determination is changed and the sensitivity is lowered (see Table 1).

The use of $10 \mathrm{~V} \mathrm{~s}^{-1}$ is a reasonable approach for the determination of both analytes, as the XA peak presented a lower resolution at higher scan rates 22 .

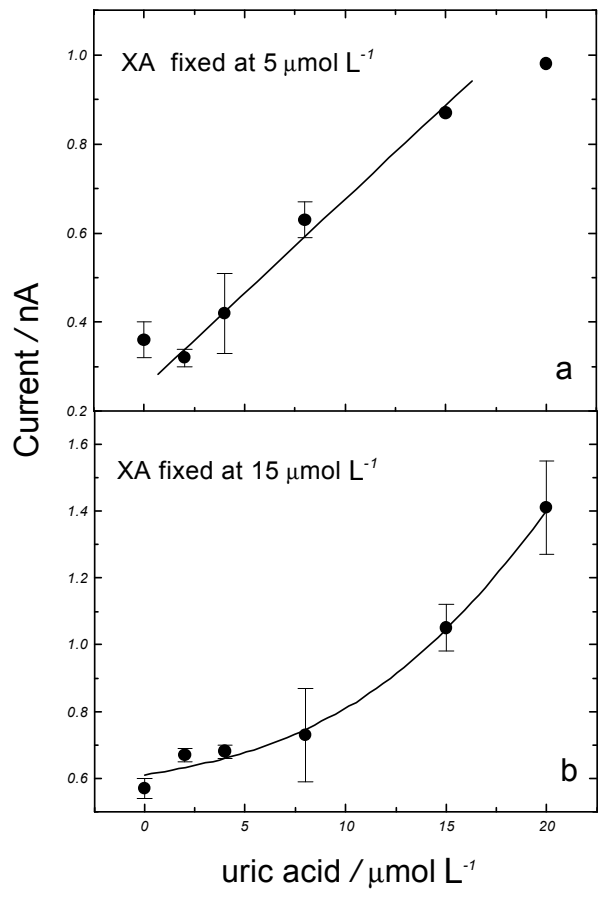

\section{Simultaneous determination of $X A, H X$ and $U A$}

In these experiments mixtures of XA, $\mathrm{HX}$ and $\mathrm{UA}$ at the same concentration have been prepared and the currents measured for each compound at $10 \mathrm{~V} \mathrm{~s}^{-1}$, after 100 cycles in $70 \mathrm{mmol} \mathrm{L}^{-1}$ phosphate buffer, $\mathrm{pH}$ 7.4. The results are summarized in Table 2. It was concluded that it is possible to determine the three compounds in the same sample without interference at this concentration level.

Table 2. Analytical results for mixtures of XA, HX and UA ${ }^{\mathrm{a}}$.

\begin{tabular}{cccc}
\hline Sample & $\begin{array}{c}\mathrm{LOD}^{\mathrm{b}} \\
\mu \mathrm{mol} \mathrm{L}^{-1}\end{array}$ & $\begin{array}{c}\text { LDR } \\
\mu \mathrm{mol} \mathrm{L}^{-1}\end{array}$ & $\begin{array}{c}\text { Sensitivity } \\
\mathrm{A} \mathrm{L} \mathrm{mol}^{-1} \mathrm{~cm}^{-2}\end{array}$ \\
\hline Mixture (1:1:1 $/ \mu \mathrm{M})$ & & & \\
XA & 2 & $6-15$ & 127 \\
HX & 2 & $6-15$ & 200 \\
UA & 2 & $4-10$ & 159 \\
\hline
\end{tabular}

a. $70 \mathrm{mmol} \mathrm{L}^{-1}$ phosphate buffer $\mathrm{pH} 7.4$, UME radius $3.5 \times 10^{-4} \mathrm{~cm}$,
scan rate $10 \mathrm{~V} \mathrm{~s}^{-1}, 100$ cycles. $\mathrm{b}$ Limit of detection $=3 \mathrm{x}$ signal $/$ noise.

Recovery tests were performed in mixtures 8:6:6 $\mu \mathrm{mol} \mathrm{L} \mathrm{L}^{-1}$ of the analytes. These concentrations were chosen to be near the limit of detection and in the linear dynamic range for three purines. The results are presented in Table 3.

Table 3. Recovery tests for mixtures of $\mathrm{XA}, \mathrm{HX}$ and $\mathrm{UA}^{\mathrm{a}, \mathrm{b}}$.

\begin{tabular}{cccccc}
\hline \multicolumn{3}{c}{ Mixture / $\mu \mathrm{M}$} & \multicolumn{3}{c}{ Recovery / $\mu \mathrm{mol} \mathrm{L}^{-1}(\%)$} \\
\hline HX & XA & UA & HX & XA & UA \\
\hline 8 & 6 & 6 & $7.1(89)$ & $6.7(111)$ & $7.1(119)$ \\
6 & 6 & 8 & $7.1(118)$ & $6.7(111)$ & $8.7(108)$ \\
6 & 8 & 6 & $6.7(112)$ & $7.3(91)$ & $7.1(119)$ \\
\hline
\end{tabular}

a. Conditions as in Table 2. b. Mean of three determinations.

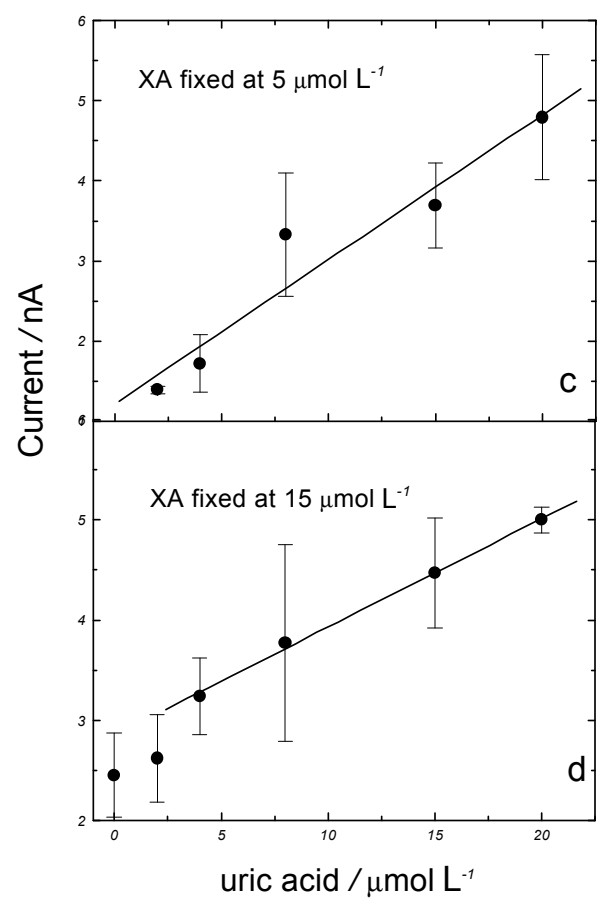

Figure 3. Influence of $5(\mathrm{a}, \mathrm{c})$ and $15(\mathrm{~b}, \mathrm{~d}) \mu \mathrm{mol} \mathrm{L} \mathrm{L}^{-1} \mathrm{XA}$ in UA analytical curves, at $10(\mathrm{a}, \mathrm{b})$ and $500(\mathrm{c}, \mathrm{d}) \mathrm{V} \mathrm{s}^{-1}$. Other conditions as in Table 2. 
The recoveries between $89-119 \%$ (mean recovery $97.6 \%$ ), were considered satisfactory in view of the complexity of the mixtures and the concentration level determined. These data suggest a positive outlook for future applications in samples of this magnitude of concentration.

The positive intercepts in all plots of Figure 3 are probably related to the presence of UA from XA oxidation. Lower detection limits have been observed in stripping methods ${ }^{7-10}$, but with the inconvenience of using the mercury electrode.

\section{References}

1. Murray, A. W. Ann. Rev. Biochem. 1971, 40, 811.

2. Harkness, R. A. J. Chromatogr. 1988, 429, 255.

3. Caraway, W. T. Stand. Methods Clin. Chem. 1963, 4, 239

4. Balis, M. E. Adv. Clin. Chem. 1967, 10, 157.

5. Simpson, R. C.; Brown, P. R. J. Chromatogr. 1986, 379, 269.

6. Glodowiski, S.; Bilewicz, R.; Kublik, Z. Anal. Chim. Acta. 1986, 186, 39.

7. Househam, B. C.; Van den Berg, C. M. G.; Riley, J. P. Anal. Chim. Acta. 1987, 200, 291.

8. Shubietah, R.M.; Abu-Zuhri, A.Z.; Fogg, A.G.; Electroanalysis 1995, 7, 975
9. Ibrahim, M. S.; Ahmed, M. E.; Kawade, A. M.; Temerk, Y. M. Analusis 1996, 24, 6.

10. Ibrahim, M. S.; Ahmed, M.E.; Temerk, Y. M.; Kawade, A. M. Anal. Chim. Acta 1996, 328, 47.

11. Palacek, E. Anal. Biochem. 1980, 108, 129.

12. Ianiello, R. M.; Lindsay, T. J.; Yacynych, A. M. Anal. Chem. 1982, 54, 1980.

13. McKenna, K.; Brajter-Toth, A. Anal. Chem. 1987, 59, 954.

14. Yao, T. Anal. Chim. Acta 1993, 281, 323.

15. Arai, G.; Takahashi, S.; Iasumori, I. J. Electroanal. Chem. 1996, 410, 173.

16. Cavalheiro, E. T. G.; Brajter-Toth, A. J. Pharm. Biomed. Anal. 1999, 19, 217.

17. Hsueh, C.C.; Bravo, R.; Jaramillo, A.; Brajter-Toth, A.; Anal. Chim. Acta 1997, 349, 67.

18. Hsueh, C. C.; Brajter-Toth, A. Anal. Chim. Acta 1996, 321, 209.

19. Hansen, B. H.; Dryhurst, G. J. Electroanal. Chem. 1971, 30, 417.

20. Conway, A. C.; Goyal, R. N.; Dryhurst, G. J. Electroanal. Chem. 1981, 123, 243.

21. Goyal, R. N.; Mittal, A.; Sharma, S. Electroanalysis 1994, 6, 609

22. Cavalheiro, E. T. G.; Bravo R.; Brajter-Toth, A. In Pittcon'99, New Orleans (USA), 1998, 1684P.

Received: May 31, 1999

Published on the web: August 31, 2000

FAPESP helped in meeting the publication costs of this article. 